\title{
NEOPTERIN AND INTERFERON-GAMMA AS IMMUNE RESPONSE MARKERS IN BETA- THALASSEMIA MAJOR PATIENTS
}

\author{
SHAHAD F OBEID ${ }^{1}$, SANAD B AL-A'ARAJI ${ }^{1}$, BASSAM F MATTI ${ }^{2}$, HAYDER ADNAN FAWZI ${ }^{3 *}$ \\ ${ }^{1}$ Department of Biochemistry, College Science for Women, University of Baghdad, Baghdad, Iraq. ${ }^{2}$ Haematology Specialist, Medical City \\ Complex, Baghdad Teaching Hospital, Baghdad, Iraq. ${ }^{3}$ Clinical Pharmacist, Medical City Complex, Baghdad Teaching Hospital, Baghdad, \\ Iraq. Email: hayder.adnan2010@ierit.nahrainuniv.edu.iq
}

Received: 12 April 2018, Revised and Accepted: 19 May 2018

ABSTRACT

Objective: The assessment of neopterin and interferon-gamma (IFN- $\gamma$ ) levels as a part of immune system response about serum iron status in $\beta$-thalassemia (TM) major patients.

Methods: Spectrophotometry applied for the estimation of iron status including serum iron level, total iron-binding capacity, and unsaturated ironbinding capacity. Enzyme-linked immunosorbent assay (ELISA) applied for the estimation of the serum cytokines included neopterin and IFN- $\gamma$ also serum ferritin estimation by ELISA from $130 \beta$-TM major patients where they divided according to serum ferritin level $(<\mathrm{and} \geq 2500 \mathrm{ng} / \mathrm{mL})$.

Results: The neopterin and IFN- $\gamma$ concentration showed significantly increased with direct correlation among TM patient group when compared to the normal healthy control group. However, there was no significant difference between different levels of serum ferritin.

Conclusion: The increased serum level of neopterin and IFN- $\gamma$ found in patients with $\beta$-TM may be due to the direct effect of iron on cellular immune cells beside of immune system response to the effect of iron toxicity on different body organs. There was a direct moderate relationship between neopterin and IFN- $\gamma$.

Keywords: Thalassemia major, Interferon-gamma, Neopterin.

(C) 2018 The Authors. Published by Innovare Academic Sciences Pvt Ltd. This is an open access article under the CC BY license (http://creativecommons. org/licenses/by/4. 0/) DOI: http://dx.doi.org/10.22159/ajpcr.2018.v11i9.26661

\section{INTRODUCTION}

The hereditary anemia $\beta$-thalassemia ( $\beta$-TM) characterized by defects in the production of the $\beta$-globin chains [1]. The ineffective erythropoiesis in $\beta$-TM is due to defective hemoglobin synthesis, which leads to severe anemia, increased erythrocyte turnover, and excessive iron absorption [2]. Neopterin is a compound isolated from the larvae of bees, from worker bees, and from royal jelly [3,4]. It is a 2-amino-4--hydroxy-(1,2,3-trihydroxypropyl)-pteridine with a low molecular mass $(253 \mathrm{Da})$. In humans, it is produced by activated monocytes/macrophages from guanosine triphosphate (GTP) through GTP cyclohydrolase I. The activity of this enzyme is greatly enhanced by interferon-gamma (IFN- $\gamma$ ) and, to a lesser degree, by IFN- $\alpha$, other cytokines, and endotoxins [5,6]. A wide spectrum of immune abnormalities has described in reports of numerous studies on patients with $\beta$-TM who have iron overload [7]. The abnormalities observed to date are both quantitative and functional and involve several components of the immune response [8]. The susceptibility to infections found in both splenectomised and non- splenectomised patients; which caused by the interaction of excess free iron with cells of the immune system as consequence of iron overload [9].

It has suggested that a variety of factors, including non-splenectomy, iron overload, repeated exposure to foreign antigens at the time of blood transfusion, and the use of chelating agents, may induce profound deleterious effects on the immune system [10]. An increase in the serum level of neopterin associated with diseases involving the cellular immune response [11]. In Iraqi, still there is no awareness about the effect of iron overload in immunity status beside overall the world, there is still debate on this issue as some of articles say that there is suppression of immune system in iron overload and other said that there is stimulation of immune system through immunogenicity of body tissue in TM major patients. The aim of this study was to the evaluation of neopterin and IFN- $\gamma$ as a part of body immune system response about serum iron status with $\beta$-TM major patients in Baghdad Medical City Hospital.

\section{METHODS}

This prospective study was carried out on 130 blood transfusiondependent patients with TM major (non-splenectomized), mean age (year) was $13.56 \pm 4.72$. The study includes three groups: The first group was $65 \mathrm{TM}$ patients with serum ferritin $<2500 \mathrm{ng} / \mathrm{mL}$ (Group A), $65 \mathrm{TM}$ patients with serum ferritin $\geq 2500 \mathrm{ng} / \mathrm{mL}$ (Group B), while Group C was 65 persons' healthy subjects as a control group. All patients selected had no clinical history of recent infection, fever, DM, and viral hepatitis infection. The serum levels of ferritin, neopterin, and IFN- $\gamma$ were assayed by enzyme-linked immunosorbent assay (ELISA) (Reader and Printer Systems, USA) and ELISA (Washer system, Australia); iron status levels were assessed by spectrophotometry (Ce Cecil, England) for all three groups.

Written informed consent obtained from all patients, the study was approved by the Ethical Committee from College Science for Women/ University of Baghdad and was in accordance with Helsinki declaration for clinical research.

Statistical analyses were conducted using the statistical software package of SPSS version 20.0.0. Differences between groups were assessed by the Mann-Whitney U-test for non-parametric variables. Pearson's correlation coefficients were calculated to evaluate the association between relevant parameters. Statistical significance was set at $\mathrm{p}<0.05$.

\section{RESULTS}

As in Table 1, there was the statistically significant difference in serum iron status levels including serum iron, total iron bounding capacity "total 
iron-binding capacity [TIBC]," unsaturated iron-binding capacity [UIBC], and serum ferritin among the studied and control groups with $\mathrm{p}<0.001$.

There was the statistically significant difference $(p<0.001)$ found among all studied TM patients with high serum level of neopterin and IFN- $\gamma$ concentration when compared to the healthy control group, as illustrated in Table 2 .

In Fig. 1, there is a direct moderate significant correlation $(\mathrm{r}=0.517$, $\mathrm{p}<0.001)$ between IFN- $\gamma$ level and neopterin parameters within TM patients group.

The results in Table 3 showed the correlation between neopterin and serum ferritin level. Serum level of neopterin correlated strongly and positively $(\mathrm{p}<0.001)$ with serum ferritin $(\mathrm{r}=0.648)$ in all thalassemic patient's; however, this relationship became weak and non-significant after we divided the serum ferritin level into two groups (using $2500 \mathrm{ng} / \mathrm{mL}$ as a cut point), as illustrated in Table 3 .

Again the results in Table 4 showed the correlation between IFN- $\gamma$ and serum ferritin level. Serum level of IFN $-\gamma$ moderately and positively correlated $(\mathrm{p}<0.001)$ with serum ferritin $(\mathrm{r}=0.483)$ in all thalassemic patient's; however, this relationship became weak and non-significant after we divided the serum ferritin level into two groups (using $2500 \mathrm{ng} / \mathrm{mL}$ as cut point), as illustrated in Table 4

\section{DISCUSSION}

Our body developed the capacity to modulate cellular iron metabolism not only for its optimal utilization as a catalyst for the generation of

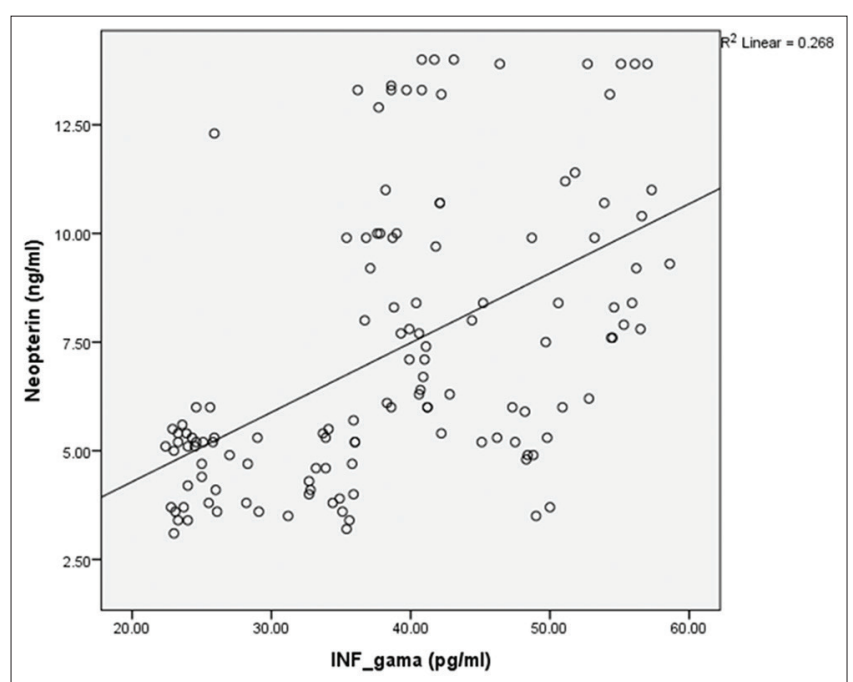

Fig. 1: Correlation between serum levels of Interferon-gamma versus neopterin in all thalassemic patients $(n=130)$ reactive oxygen species acting as strong antimicrobial molecules but also to make iron less available for the microorganisms [12,13], from this concept, the current study established trying to understand effect of iron overload on immune system. Here, in our studied TM patients group had significantly higher iron body status, as serum level of iron was significantly higher in thalassemic patients compared to healthy control ( $209.3 \pm 70.3$ vs. $70.26 \pm 6.25$ ), TIBC was significantly higher in thalassemic patients compared to healthy control $(627.9 \pm 210.9$ vs. $210.79 \pm 18.75$ ), UIBC was significantly higher in thalassemic patients compared to healthy control $(74.9 \pm 25.2$ vs. $25.15 \pm 2.24)$, and serum ferritin was significantly higher in thalassemic patients compared to healthy control $(3439.5 \pm 2299$ vs. $70.94 \pm 15.82)$ also. This findings of the current study were in agreement with Ayoub et al., [14] Hadeed et al., [15] and Abdulzahra et al. [16] studies. Iron overload is common in TM major, and it is responsible for many of the other complications that occur in these disorders. Iron overload may result from a combination of ineffective erythropoiesis, which promotes increased intestinal iron uptake, and due to frequent blood transfusion because of chronic anemia. The contribution of ineffective erythropoiesis is significant.

In the current study, serum IFN- $\gamma$ was significantly increased in thalassemic patients compared to control group $(38.6 \pm 10.5$ vs. $5.55 \pm 1.70) \mathrm{p}<0.001$, and as iron overload increases, the IFN- $\gamma$ significantly became higher (45.01 \pm 7.54 vs. $32.09 \pm 8.90, \mathrm{p}<0.001)$; in both high and low iron overload, respectively, which may be due to activation of the immune system because of the direct effect of iron on different body organs including cellular immunity causing activation of monocular cells and increase of IFN- $\gamma$, and other relaying cytokines even in the absence of secondary infection [17]. Our finding was in agreement with Salsaa and Zoumbos in which they found that IFN- $\gamma$ produced more among TM patients compared to control [18], while in another Iranian study, Gharagozloo et al. reported the opposite in which IFN- $\gamma$ was lower in TM patients, they attributed these controversial findings to selection of their patients in which their patients did not have infections nor any acute or chronic disease that may affect IFN- $\gamma$ serum levels, although our study also excluded the presence of infection or chronic disease before including the patients in the study [2]. A difference in the exclusion criteria in the current study compared to the above studies leads to this variation in IFN $-\gamma$ levels.

Again the serum level of neopterin was also significantly higher in TM patients compared to control $(7.25 \pm 3.23$ vs. $1.27 \pm 0.65, p<0.001)$, and among high iron overload group compared to low iron overload group $(9.83 \pm 2.62$ vs. $4.67 \pm 0.83, p<0.001)$ too. Our findings were in agreement with Shanab et al. (2014) 19.0 versus $9.0 \mathrm{mmoL} / \mathrm{L}$ [19]. The IFN- $\gamma$ is responsible for stimulation of neopterin synthesis (a catabolic product of GTP) and then produced by macrophages indicating its role as a marker for cellular immunity activation $[20,21]$. In the current study, we found a direct strong correlation between both neopterin and IFN- $\gamma$ $(\mathrm{r}=0.517, \mathrm{p}<0.001)$ in TM patients, which is in agreement with previous studies $[20,21]$ since IFN- $\gamma$ is the most potent activator of neopterin production in human cells, this explains why both were elevated in

Table 1: Iron study analysis among different studied groups

\begin{tabular}{lll}
\hline Variables & Healthy individuals $(\mathbf{n}=\mathbf{6 5})$ & All thalassemic $(\mathbf{n}=\mathbf{1 3 0})$ \\
\hline Iron $(\mu \mathrm{mol} / \mathrm{L})$, mean \pm SD & $70.26 \pm 6.25$ & $209.3 \pm 70.3$ \\
TIBC, mean \pm SD & $210.79 \pm 18.75$ & $627.9 \pm 210.9$ \\
UIBC, mean \pm SD & $25.15 \pm 2.24$ & $74.9 \pm 25.2$ \\
Ferritin $(\mathrm{ng} / \mathrm{mL})$, mean \pm SD & $70.94 \pm 15.82$ & $3439.5 \pm 2299$ \\
\hline
\end{tabular}

TIBC: Total iron-binding capacity, UIBC: Unsaturated iron-binding capacity

Table 2: Assessment of neopterin and IFN $-\gamma$ among the studied groups

\begin{tabular}{lll}
\hline Variables & Healthy individuals $(\mathbf{n = 6 5 )}$ & All thalassemic (n=130) \\
\hline IFN- $\gamma(\mathrm{pg} / \mathrm{mL})$, mean \pm SD & $5.54 \pm 1.70$ & $38.55 \pm 10.47$ \\
Neopterin $(\mathrm{ng} / \mathrm{mL})$, mean \pm SD & $1.27 \pm 0.65$ & $7.25 \pm 3.23$ \\
\hline
\end{tabular}

IFN- $\gamma$ : Interferon-gamma 
Table 3: Correlation between neopterin among different serum ferritin levels

\begin{tabular}{lll}
\hline Variable & Neopterin & \\
\cline { 2 - 3 } & $\mathbf{r}$ & p value \\
\hline All patients & 0.648 & $<0.001$ \\
Ferritin $<2500$ & 0.225 & 0.071 \\
Ferritin $\geq 2500$ & 0.122 & 0.334 \\
\hline r: Pearson's correlation coefficient & &
\end{tabular}

Table 4: Correlation between IFN- $\gamma$ and serum ferritin levels

\begin{tabular}{lll}
\hline Variable & IFN- $\boldsymbol{\gamma}(\mathbf{p g} / \mathbf{m L})$ & \\
\cline { 2 - 3 } & $\mathbf{r}$ & p value \\
\hline All patients & 0.0483 & $<0.001$ \\
Ferritin $<2500 \mathrm{ng} / \mathrm{mL}$ & 0.235 & 0.059 \\
Ferritin $\geq 2500 \mathrm{ng} / \mathrm{mL}$ & 0.007 & 0.953 \\
\hline
\end{tabular}

r: Pearson's correlation coefficient, IFN- $\gamma$ : Interferon-gamma

TM patients group. As neopterin has an indirect inhibitory effect on erythropoiesis, as some studies suggested when it added to a perfusion fluid, neopterin causes a decrease in erythropoietin mRNA levels [20] so that we should be aware of other causes of anemia in TM patients which may help to decrease the frequency of blood transfusion beside strict control of iron level with serum ferritin lower than $1000 \mathrm{ng} / \mathrm{mL}$.

\section{RECOMMENDATION}

The increased serum level of neopterin and IFN $-\gamma$ found in patients with $\beta$-TM may be due to effects of iron overload on immune system cells and other damaged body organs causing activation and releasing different cytokines and immune markers regardless the presence of infection.

We recommend studying the neopterin level in patients with TM major patients with $<1000 \mathrm{ng} / \mathrm{mL}$, and its relation to the frequency of blood transfusion in major TM patients.

\section{AUTHOR'S CONTRIBUTION}

Concept and collection of data - Shahad F Obeid. Writing the article and critical review of the article - Shahad F Obeid and Bassam F Matti. Final approval of the article - Sanad B AL-A'Araji.

\section{CONFLICTS OF INTEREST}

The authors declare that they have no conflicts of interest.

\section{REFERENCES}

1. Thakur S, Raw SN, Sharma R. Study the level of awareness among sindhi families of durg, chhattisgarh (India): A questionnaire based statistical study. Int J Parm Pharm Sci 2015;7:341-6.

2. Gharagozloo M, Karimi M, Amirghofran Z. Double-faced cellmediated immunity in beta-thalassemia major: Stimulated phenotype versus suppressed activity. Ann Hematol 2009;88:21-7.

3. Devarshi S, James S, Najafzadeh E, Pawar S, Kalrao V, Bafna V. Assessment of quality of life, complications and post-transfusion adverse reactions in thalassemia pediatric in tertiary care hospital. Int $\mathrm{J}$ Parm Pharm Sci 2016;8:317-23.

4. Eisenhut M. Neopterin in diagnosis and monitoring of infectious diseases. J Biomark 2013;2013:1-10.

5. Elbakry KA, Malak CA, Howas MM. Immunomodulatory role of honey and propolis on carbon tetrachloride $(\mathrm{CCl} 4)$ injected rats. Int $\mathrm{J}$ Parm Pharm Sci 2015;7:282-8.

6. Wietlicka-Kokoszanek I, Jablecka A, Smolarek I, Bogdanski P, Korzeniowska K, Kazmierczak M, et al. Neopterin as a prognostic marker in patients with chronic heart failure. Med Sci Mon 2010;16:CR232-7.

7. Thakur S, Raw SN, Sharma R. Design of a fuzzy model for thalassemia disease diagnosis: Using mamdani type fuzzy inference system (FIS). Int J Parm Pharm Sci 2016;8:356-61.

8. Farmakis D, Giakoumis A, Aessopos A, Polymeropoulos E. Pathogenetic aspects of immune deficiency associated with $B$ thalassemia. Med Sci Mon 2003;9:RA19-22.

9. Fadhil RK, Mohammed HQ, Faraj SA. Evaluation of cellular immunity for $\beta$-thalassemia major patients in wasit thalassemia center. Int J Micro Gen Monocular Res 2017;3:1-8.

10. Amin A, Jalali S, Amin R, Aale-Yasin S, Jamalian N, Karimi M. Evaluation of the serum levels of immunoglobulin and complement factors in b-thalassemia major patients in Southern Iran. IJI 2005;2:220-5.

11. Fuchs D, Avanzas P, Arroyo-Espliguero R, Jenny M, ConsuegraSanchez L, Kaski J. The role of neopterin in atherogenesis and cardiovascular risk assessment. Curr Med Chem 2009;16:4644-53.

12. Radtke AL, O'Riordan MX. Intracellular innate resistance to bacterial pathogens. Cell Micro 2006;8:1720-9.

13. Weinberg ED. Iron withholding as a defense strategy. In: Hershko R, Gordeuk V and Weiss G, editors. Anemia of Chronic Disease. Boca Raton: Taylor and Francis Group; 2005. p. 255-80.

14. Ayoub N, Khaleed JK, Mohammed II. Hypothyroidism in transfusiondependent Genetics $\beta$-thalassemia. Iraqi J Can and Med 2016;9:36-40.

15. Hadeed WA, Alhially YA, Bashi AY. Comparison of thyroid function tests between splenectomised and non-splenectomised $\beta$-thalassemia major patients. Tik J of Pure Sci 2015;20:61-6.

16. Abdulzahra MS, Al-Hakeim HK, Ridha MM. Study of the effect of iron overload on the function of endocrine glands in male thalassemia patients. Asian J Transfus Sci 2011;5:127-31

17. Maurya SK, Bisht P, Semwal M, Gandhi S. An updates on the sepsis causing multiple organ dysfunctions. J Crit Rev 2016;3:31-40.

18. Salsaa B, Zoumbos NC. A distinct pattern of cytokine production from blood mononuclear cells in multi-transfused patients with $\beta$-thalassaemia. Clin Exp Immunol 1997;107:589-92.

19. Abo Shanab AM, El-Desouky MA, Kholoussi N, El-Kamah G, Fahmi A. Evaluation of neopterin as a prognostic factor in relation to cytokines and immunoglobulins in patients with $\beta$-mediated anemia. Arch El Med 2015;32:60-5.

20. Berdowska A, Zwirska-Korczala K. Neopterin measurement in clinical diagnosis. J Clin Pharm Ther 2001;26:319-29.

21. Murr C, Widner B, Wirleitner B, Fuchs D. Neopterin as a marker for immune system activation. Curr Drug Meta 2002;3:175-87. 